\title{
Sodium-Based Chitosan Polymer Embedded with Copper Selenide (CuSe) Flexible Film for High Electromagnetic Interference (EMI) Shielding Efficiency
}

\author{
Nurul Huda Osman ${ }^{1,2,3, *}$, Nurul Najiha Mazu ${ }^{1}$, Josephine Ying Chyi Liew ${ }^{1,2}{ }^{10}$, \\ Muhammad Mahyiddin Ramli ${ }^{3,4}$, Andrei Victor Sandu ${ }^{5}{ }^{\circ}$, Marcin Nabiałek ${ }^{6}\left(\mathbb{C}^{\circ}\right.$, \\ Mohammad Abdull Halim Mohd Abdull Majid ${ }^{1,2}$ and Hazeem Ikhwan Mazlan ${ }^{1}$
}

check for updates

Citation: Osman, N.H.; Mazu, N.N.; Ying Chyi Liew, J.; Ramli, M.M.; Sandu, A.V.; Nabiałek, M.; Abdull Majid, M.A.H.M.; Mazlan, H.I. Sodium-Based Chitosan Polymer Embedded with Copper Selenide (CuSe) Flexible Film for High Electromagnetic Interference (EMI) Shielding Efficiency. Magnetochemistry 2021, 7, 102. https://doi.org/ 10.3390/magnetochemistry7070102

Academic Editor: Carlos J.

Gómez García

Received: 9 May 2021

Accepted: 5 July 2021

Published: 12 July 2021

Publisher's Note: MDPI stays neutral with regard to jurisdictional claims in published maps and institutional affiliations.

Copyright: (c) 2021 by the authors. Licensee MDPI, Basel, Switzerland. This article is an open access article distributed under the terms and conditions of the Creative Commons Attribution (CC BY) license (https:/ / creativecommons.org/licenses/by/ $4.0 /)$.
1 Applied Electromagnetic Laboratory 1, Department of Physics, Faculty of Science, Universiti Putra Malaysia (UPM), Serdang 43400, Selangor, Malaysia; najihamazu@gmail.com (N.N.M.); josephine@upm.edu.my (J.Y.C.L.); hmajid70@gmail.com (M.A.H.M.A.M.); hazeemikhwan.mazlan@gmail.com (H.I.M.)

2 Materials Synthesis and Characterization Laboratory, Institute of Advanced Technology, Universiti Putra Malaysia (UPM), Serdang 43400, Selangor, Malaysia

3 Geopolymer \& Green Technology, Center of Excellence (CEGeoGtech), Pauh Putra Campus, Universiti Malaysia Perlis (UniMAP), Arau 02600, Perlis, Malaysia; mmahyiddin@unimap.edu.my

4 Faculty of Electronic Engineering Technology, Universiti Malaysia Perlis (UniMAP), Kangar 01000, Perlis, Malaysia

5 Faculty of Materials Science and Engineering, Gheorghe Asachi Technical University of Iasi, Blvd. D. Mangeron 41, 700050 Iasi, Romania; sav@tuiasi.ro

6 Department of Physics, Częstochowa University of Technology, 42-201 Częstochowa, Poland; nmarcell@wp.pl * Correspondence: nurulhuda@upm.edu.my

\begin{abstract}
Efficient shielding materials are extremely important to minimize the effect of electromagnetic interference. Currently, various composite materials are being investigated with different shielding efficiencies reported. In this paper, a flexible and free-standing sodium-based chitosan $(\mathrm{CH} / \mathrm{Na})$ polymer with copper selenide (CuSe) filler was prepared for electromagnetic shielding. $\mathrm{The} \mathrm{CH} / \mathrm{Na} / \mathrm{CuSe}$ polymer matrix was prepared via the direct casting technique at different $\mathrm{wt} \%$ of CuSe, varying from 2 to $20 \mathrm{wt} \%$. The polymer matrix was then characterised by using Fourier transform infrared (FTIR) spectroscopy to confirm the interaction between the $\mathrm{CH} / \mathrm{Na}$ and CuSe. The XRD results revealed that the $\mathrm{CH} / \mathrm{Na} / \mathrm{CuSe}$ polymer was successfully formed. Improvement in the electrical conductivity was confirmed by an impedance spectroscopy measurement. The highest electrical conduction recorded was at $3.69 \times 10^{-5} \mathrm{~S} / \mathrm{cm}$ for $\mathrm{CH} / \mathrm{Na} / \mathrm{CuSe}$ polymer matrix with $20 \mathrm{wt} \% \mathrm{CuSe}$. An increase in total electromagnetic interference (EMI) shielding efficiency $\left(\mathrm{SE}_{\mathrm{T}}\right)$ of up to $20 \mathrm{~dB}$ (99\% EM power shield) was achieved, and it can be increased up to $34 \mathrm{~dB}(99.9 \%$ EM power shield) with the thickness of the polymer increased.
\end{abstract}

Keywords: electromagnetic interference; EMI shielding; conducting polymer; impedance spectroscopy

\section{Introduction}

Electromagnetic interference (EMI) is an electromagnetic signal that interferes with other electronic equipment regular operations. Interference is one of the many challenges in the rapid growth of smart electronic devices which operate at a high frequency [1]. Many of these electronic devices are placed in plastic cases that provide no shielding, making them susceptible to incoming/outgoing interference that can cause device malfunctions. Conventional methods of using a solid or mesh metal gasket for EMI shielding are effective. However, the metal gasket is expensive, has a high mass density, is inflexible, and is easily exposed to corrosion [2]. Lightweight and flexible materials are useful, especially in personal electronic devices and the aerospace industry, in which weight, size, and high EMI shielding are important. 
In recent years, works on the use of conductive polymers to replace pure metal for EMI shielding have been on the rise $[3,4]$. Conductive polymers have high conduction and offer higher shielding efficiency compared to standard, nonconducting polymers. Works that utilised either ionic conductivity, electron conductivity, or both have been reported $[5,6]$. Works improving polymer conductivity by chemical modification of the polymer chain or by a mechanical process of inserting highly conductive material as filler into the polymer matrix have also been included [7].

Copper Selenide (CuSe) is a type of binary metal chalcogenide compound with a semiconductor structure. CuSe has received extensive attention due to its unique electrical and optical properties [8-10]. This material can be formed into various types of crystallographic structures, such as orthorhombic, monoclinic [11], cubic [12,13], tetragonal, and hexagonal [14,15]. Various crystallographic structures make them essential for specific applications, such as solar cells, superionic conductors, photodetectors, Shottky diodes [16-19], sensors, polarisers, and thermoelectric devices [15,20]. The reported value of CuSe electrical conductivity in the range of $8.24 \times 10^{2}$ to $1.03 \times 10^{3} \mathrm{~S} / \mathrm{cm}$ [20] seemed to have a high potential for EMI shielding purposes. However, CuSe is a nonferrous material with zero magnetic moments detected in an undoped CuSe sample [21]. Hence, the shielding will depend solely on the electrical properties of the CuSe sample.

Chitosan's properties, such as nontoxicity, biodegradability, and antimicrobial properties, have made it attractive for many applications, such as in biotechnology, pharmacies, drugs, food, and biosensors [22]. Chitosan is a nonconducting polymer in its initial state with hydroxyl $(-\mathrm{OH})$ and amino $\left(-\mathrm{NH}_{2}\right)$ groups available as binding sites for metal ions. Adsorption of metal ions into the binding sites of chitosan cause the resistivity of the polymer to decrease and overall conductivity to increase [23]. Works on chitosan for polymer electrolytes show an increase in conduction from $1.91 \times 10^{-4} \mu \mathrm{S} / \mathrm{cm}$ for pure chitosan to $2.41 \times 10^{-4} \mathrm{~S} / \mathrm{cm}$ with the addition of $40 \mathrm{wt} \%$ of NaTf salt, and for works on a $\mathrm{CS} \mathrm{AgNO}_{3}$ system doped with $1 \mathrm{wt} \%$ alumina, the conduction increased to $2.3 \times 10^{-6} \mathrm{~S} / \mathrm{cm}[24,25]$. In a work using $\mathrm{Li}^{+}$ions at a different percentage glycerolized in chitosan film, a $5.19 \times 10^{-4} \mathrm{~S} / \mathrm{cm}$ conduction was shown to be obtained [26]. The presence of ions changes the chitosan polymer from pure dielectric to a dielectric-conductor composite, having overall conductivity in the conducting polymer region.

This work focused on producing a polymer matrix using sodium-based chitosan embedded with CuSe as a conductive filler in an EMI shielding application. The addition of a conductive filler will enhance the polymer's electrical properties with lower resistance and better conductivity, which will increase its total EMI shielding effectiveness.

\section{Methodology}

\subsection{Material}

Chitosan with medium molecular weight (75-85\% deacetylation, Mw 190,000-310,000 Da) and acetic acid (99\% purity) were purchased from Sigma-Aldrich (Burlington, VT, USA). Sodium ion standard solution $(1000 \mathrm{mg} / \mathrm{L})$ was purchased from Fischer Scientific (Hampton, NH, USA). The working solutions of sodium ion concentrations $(100 \mathrm{mg} / \mathrm{L})$ was obtained by diluting the $1000 \mathrm{mg} / \mathrm{L}$ standard solution with deionised water. All chemical reagents employed during chemical coprecipitation to make the $\mathrm{CuSe}$ nanoparticles powder, such as $\mathrm{CuCl}_{2} \cdot 2 \mathrm{H}_{2} \mathrm{O}$ (Fisher Scientific), Se metal powder (HmbG Chemicals), and $\mathrm{NaOH}$ (Fisher Scientific), were of analytical grade and were used without further purification.

\subsection{Cuse Synthesis}

The CuSe powder was synthesised via the chemical coprecipitation method [20]. Elemental selenium was completely dissolved in $12 \mathrm{Mol} / \mathrm{L} \mathrm{NaOH}$ solution and mixed with $\mathrm{Cu}^{2+}$ solution obtained from $0.03 \mathrm{~mol} \mathrm{CuCl} 2 \cdot 2 \mathrm{H}_{2} \mathrm{O}$ to form black precipitates. The reaction mixture was stirred for another $24 \mathrm{~h}$ to ensure complete reaction. The black precipitates were centrifuged and washed several times with distilled water to remove the unreacted, 
unabsorbed, or excess selenium ions. The powdered precipitate was oven dried at $70{ }^{\circ} \mathrm{C}$ for $24 \mathrm{~h}$.

\subsection{Film Fabrication}

The Na-based chitosan polymer solution was prepared by dissolving $2 \mathrm{~g}$ of medium molecular weight chitosan in $50 \mathrm{~mL}$ of $\mathrm{Na}$ solution at $100 \mathrm{mg} / \mathrm{L}$ concentration. Then, acetic acid ( $1 v / v \%)$ was added to the solution and stirred until a homogeneous solution was obtained. Once the homogeneous solution was obtained, 1\% of glycerol was added as plasticizer to the chitosan solution and stirred for an additional $4 \mathrm{~h}$.

The ready CuSe powder was dispersed into deionised water at the required weight percentage, ranging from $2 \mathrm{wt} \%$ to $20 \mathrm{wt} \%$ and sonicated for $2 \mathrm{~h}$. Then, the dispersed $\mathrm{CuSe}$ filler was mixed with prepared $\mathrm{Na}$-based chitosan solution and further sonicated to promote the interaction between chitosan and CuSe nanoparticles. The final solution was directly cast and oven dried at $60^{\circ} \mathrm{C}$ for $24 \mathrm{~h}$.

\section{Characterization}

The impedance measurement was conducted by using an electrochemical workstation (ZIVE SP1, WonA Tech, Seoul, Korea) with frequency between $10 \mathrm{~Hz}$ and $1 \mathrm{MHz}$ at room temperature. The polymer films were placed between two stainless steel electrodes with a diameter of $2 \mathrm{~cm}$. The bulk resistance $\left(R_{B}\right)$ obtained from the Nyquist plot was used to calculate the conductivity $(\sigma)$ by using Equation (1):

$$
\sigma=\frac{t}{R_{B} A}
$$

where $t$ is the polymer film thickness, and $\mathrm{A}$ is the electrode area.

The dielectric permittivity of the polymer film, which provided information on the polarisation effect, ability to store charge, and loss, was also investigated. Dielectric permittivity is a complex value, whereby the real part consists of dielectric constant $\left(\varepsilon_{\mathrm{r}}\right)$, while the imaginary part consists of dielectric loss $\left(\varepsilon_{\mathrm{i}}\right)$. These values can be deduced for the dielectric constant and dielectric loss values from the complex impedance, as shown in Equations (2) and (3) [27]. The Co is capacitance of the empty cell electrode, and $Z_{\mathrm{r}}$ is the real part of impedance, while $Z_{i}$ is the imaginary part, and $\omega$ is the angular frequency:

$$
\begin{aligned}
& \varepsilon_{\mathrm{r}}=\frac{\mathrm{Z}_{\mathrm{r}}}{\omega \mathrm{C}_{\mathrm{o}}\left(\mathrm{Z}_{\mathrm{r}}^{2}+\mathrm{Z}_{\mathrm{i}}^{2}\right)} \\
& \varepsilon_{\mathrm{i}}=\frac{\mathrm{Z}_{\mathrm{i}}}{\omega \mathrm{C}_{\mathrm{o}}\left(\mathrm{Z}_{\mathrm{r}}{ }^{2}+\mathrm{Z}_{\mathrm{i}}{ }^{2}\right)}
\end{aligned}
$$

The shielding efficiency measurement was performed using two $X$ band waveguides connected to the vector network analyser (8510C, Agilent). All samples were cut into $23 \mathrm{~mm} \times 10 \mathrm{~mm}$ and were ensured to be flat during measurement. Full two-port calibration was done before the measurement to eliminate system error. The measurement was conducted at a frequency between $8 \mathrm{GHz}$ and $12 \mathrm{GHz}$.

The effectiveness of any material in shielding against EM waves is measured by its shielding efficiency (SE). The total shielding efficiency $\left(\mathrm{SE}_{\mathrm{T}}\right)$ is calculated based on the reflection shielding $\left(\mathrm{SE}_{\mathrm{R}}\right)$ and absorption shielding $\left(\mathrm{SE}_{\mathrm{A}}\right)$ of the polymer film. The amount of EM radiation that is absorbed depends on the electric and magnetic dipoles, while the amount reflected depends on the polymer film conductivity. Multiple reflections are neglected when the polymer thickness is more than the skin depth at the measuring frequency. For thin material, the EM energy becomes trapped and reflected between the boundaries of the material. For a thicker material (multiple skin depths thick), the multiple reflection can be neglected due to the attenuation in the material that will reduce the signal strength as it travels between the boundaries. 
The $\mathrm{SE}_{\mathrm{T}}, \mathrm{SE}_{\mathrm{A}}$, and $\mathrm{SE}_{\mathrm{R}}$ values can be calculated from Equations (4)-(6), whereby $\mathrm{S}_{11}$ is the forward reflection coefficient, and $S_{12}$ is the forward transmission coefficient [28]:

$$
\begin{gathered}
\mathrm{SE}_{\mathrm{T}}(\mathrm{dB})=\mathrm{SE}_{\mathrm{R}}+\mathrm{SE}_{\mathrm{A}} \\
\mathrm{SE}_{\mathrm{R}}(\mathrm{dB})=-10 \log \left(1-\mathrm{S}_{11}^{2}\right) \\
\mathrm{SE}_{\mathrm{A}}(\mathrm{dB})=-10 \log \left(\frac{\mathrm{S}_{12}^{2}}{1-\mathrm{S}_{11}^{2}}\right)
\end{gathered}
$$

The $\mathrm{SE}_{\mathrm{R}}$ equation can be written as a function of the shielding material conductivity as given by [29]:

$$
\mathrm{SE}_{\mathrm{R}}=-10 \log _{10}\left(\frac{\sigma}{16 \omega \mu \varepsilon_{\mathrm{o}}}\right)
$$

The $\mathrm{SE}_{\mathrm{A}}$ value mainly contributed to the ohmic loss of the shielding material. The increase in $\mathrm{SE}_{\mathrm{A}}$ can be related to the properties of the shielding material, as shown in Equation (8) [30,31]:

$$
\mathrm{SE}_{\mathrm{A}}=-20 \frac{\mathrm{t}}{\delta} \log \mathrm{e}
$$

where $t$ is the thickness, and $\delta$ is the skin depth and represented by

$$
\delta=\sqrt{\frac{2}{\omega \sigma \mu}}
$$

Therefore, $\mathrm{SE}_{\mathrm{A}}$ can be written as

$$
\mathrm{SE}_{\mathrm{A}}=-8.86 \mathrm{t} \frac{\sqrt{\mathrm{f} \mu \sigma}}{2}
$$

From Equation (10), it was noted that the $\mathrm{SE}_{\mathrm{A}}$ was also the function of material conductivity $(\sigma)$ and permeability $(\mu)$.

\section{Results and Discussion}

The resulting film from the drying process was a free-standing, opaque, and flexible polymer with thickness varying from $0.119 \mathrm{~mm}$ to $0.152 \mathrm{~mm}$. All the samples were then characterized by XRD and FTIR to observe the present of CuSe filler in the chitosan polymer, while impedance spectroscopy and a network analyser were used to investigate the electrical and shielding properties of the $\mathrm{CH} / \mathrm{Na} / \mathrm{CuSe}$ polymer matrix.

\subsection{XRD}

The XRD patterns for the $\mathrm{CH} / \mathrm{Na} / \mathrm{CuSe}$ polymer matrix with different $\mathrm{CuSe}$ concentrations $(2 \mathrm{wt} \%, 11 \mathrm{wt} \%$, and $20 \mathrm{wt} \%)$ are presented in Figure 1, as well as pure chitosan and chitosan with sodium. The peaks observed at $2 \theta=26.6^{\circ}, 28.1^{\circ}, 31.0^{\circ}, 46.0^{\circ}, 50.0^{\circ}$, and $56.6^{\circ}$ for $2 \mathrm{wt} \%, 11 \mathrm{wt} \%$, and $20 \mathrm{wt} \%$ of CuSe concentrations matched well with the JCPDS 96-900-0064 pattern, which corresponded to the hexagonal phase of klockmannite [20]. For pure chitosan, there was a characteristic peak found at a broad peak position of $\sim 20^{\circ}$, which matched the chitosan intermolecular chains alignment [32]. When a sodium ion is introduced to the chitosan matrix (denoted in black line in Figure 1), the intensity of the pure chitosan crystalline peaks decreases, and the peak at $\sim 25^{\circ}$ broadens. Chitosan becomes protonated when dissolved in dilute acetic acid, producing an electrostatic repulsion force that results in molecular swelling. The salt's ions lowered the electrostatic attraction between the amine group of chitosan, thus decreasing the swelling effect. This resulted in a reduction in the peak intensity of the chitosan, which broadened [33]. Some studies obtained a similar finding, implying that the presence of a sodium ion resulting in a lower 
intensity of the diffraction peaks indicates a reduction in crystallinity and an increase in amorphisity [34,35].

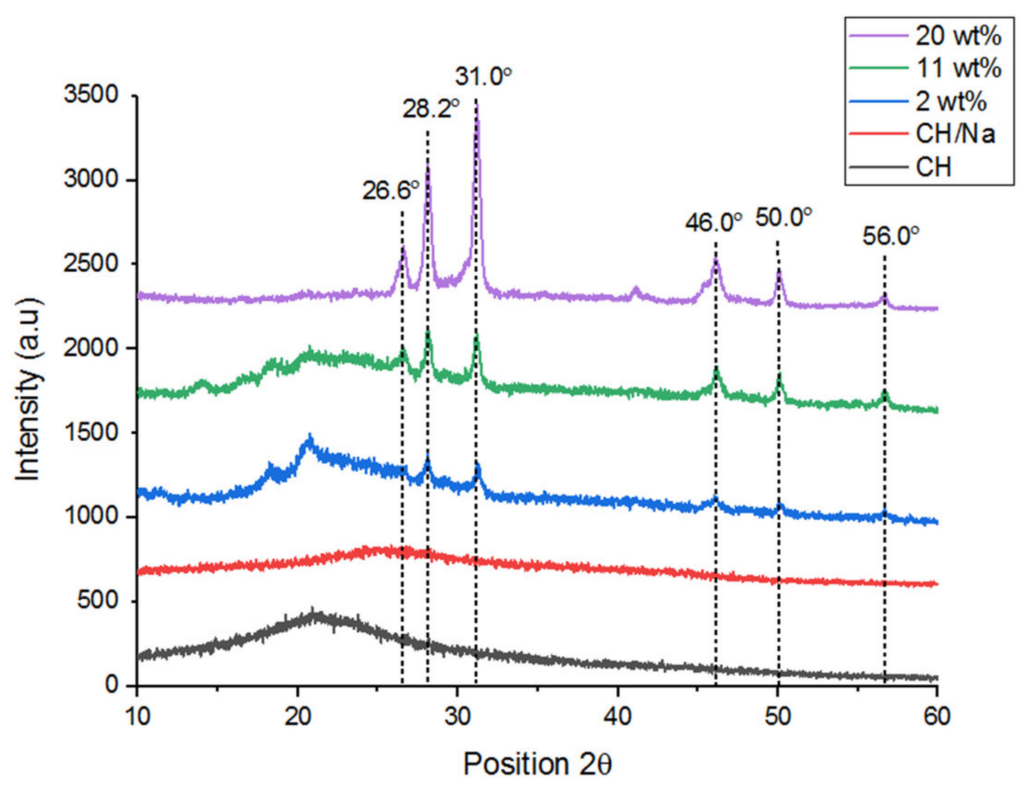

Figure 1. X-ray diffraction pattern for $\mathrm{CH}$ polymer, $\mathrm{CH} / \mathrm{Na}$ polymer, and $\mathrm{CH} / \mathrm{Na}$ /CuSe polymer matrix at different concentrations of CuSe: $2 \mathrm{wt} \%, 11 \mathrm{wt} \%$, and $20 \mathrm{wt} \%$.

The broad line shown by the chitosan peak at smaller diffraction angles suggested that long-range disorder was found in the $\mathrm{CH} / \mathrm{Na} / \mathrm{CuSe}$ polymer matrix samples. However, the presence of a broad hump became less prominent as the concentration of CuSe filler was added beyond $2 \mathrm{wt} \%$. It was observed that when the CuSe filler content increased up to $20 \mathrm{wt} \%$, the characteristic chitosan peak decreased. The intensity of the chitosan XRD peak may be approximated by the number of chitosan chains packed together. The interaction between the CuSe filler and the chitosan made the molecular interaction force inside the chitosan weaker, resulting in a reduced crystalline degree in the chitosan matrix.

\subsection{FTIR}

The FTIR spectra of pure $\mathrm{CH}$ and the $\mathrm{CH} / \mathrm{Na} / \mathrm{CuSe}$ polymer matrix with $2 \mathrm{wt} \%$, $11 \mathrm{wt} \%$, and $20 \mathrm{wt} \%$ of CuSe filler are presented in Figure 2. In the spectrum, the broadbands in the 3277-3288 $\mathrm{cm}^{-1}$ region were the overlapping peaks of $-\mathrm{NH}_{2}$ and $-\mathrm{OH}$ stretching vibrations. [36]. The band located between $2935 \mathrm{~cm}^{-1}$ and $2884 \mathrm{~cm}^{-1}$ was attributed to the $\mathrm{C}-\mathrm{H}$ stretching vibrations in the groups of $-\mathrm{CH}_{3}$ and $-\mathrm{CH}_{2}$, respectively [37]. The peaks that appeared at $1623-1640 \mathrm{~cm}^{-1}$ were related to the amide I. Meanwhile, the band at $1528 \mathrm{~cm}^{-1}$ corresponded to the $-\mathrm{NH}_{2}$ bending vibrations [38]. The $\mathrm{C}-\mathrm{N}$ stretching vibrations also occurred in the $1316 \mathrm{~cm}^{-1}$ region [37]. The absorption peaks at $1151 \mathrm{~cm}^{-1}$ and $1022 \mathrm{~cm}^{-1}$ indicated the characteristic of the $\mathrm{C}-\mathrm{O}-\mathrm{C}$ stretching vibrations $[36,37]$. The weak bands near $555 \mathrm{~cm}^{-1}$ corresponded to the $\mathrm{Cu}-\mathrm{Se}$ bending vibration, as reported in the previous literature [39]. 


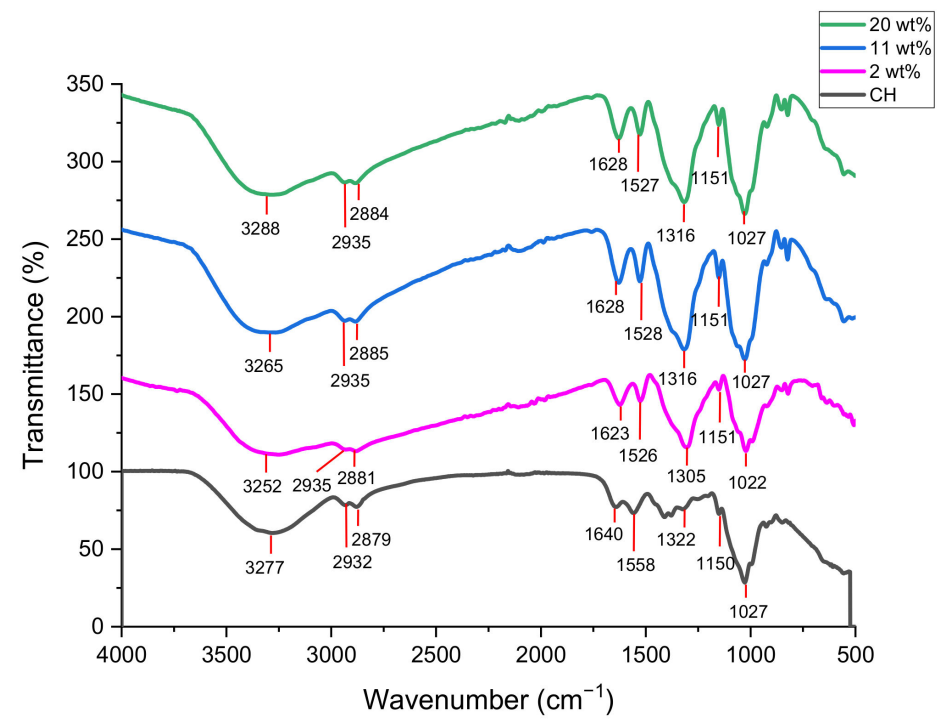

Figure 2. Infrared spectra for pure $\mathrm{CH}$ and $\mathrm{CH} / \mathrm{Na} / \mathrm{CuSe}$ polymer matrix with $2 \mathrm{wt} \%, 11 \mathrm{wt} \%$, and $20 \mathrm{wt} \%$ of CuSe filler.

\subsection{Impedance Spectroscopy Analysis}

Figure 3 shows the impedance plots for the $\mathrm{CH} / \mathrm{Na} / \mathrm{CuSe}$ polymer matrix with $2 \mathrm{wt} \%$ to $20 \mathrm{wt} \%$ of CuSe fillers measured at a frequency between $10 \mathrm{~Hz}$ and $1 \mathrm{MHz}$ at room temperature. For samples with $2 \mathrm{wt} \%$ to $11 \mathrm{wt} \%$ of CuSe filler, a complete semicircle plot was observed. For samples with $15 \mathrm{wt} \%$ and $20 \mathrm{wt} \%$ of CuSe, a semicircle with a residual spike was observed. The spike was attributed to the interface between electrode and sample [40]. As the CuSe filler concentration increased, the filler started to agglomerate and caused higher interfacial impedance. The $\mathrm{R}_{\mathrm{B}}$ value, obtained from the extrapolation of impedance plots, showed a reduction in the polymer bulk resistance of the matrix as a higher weight percentage of CuSe filler was introduced. This followed the percolation theory, suggesting that a higher concentration filler will cause the polymer to become more conductive. Furthermore, the network connection was formed by the CuSe filler, which improved the conduction path for the charge carrier [41].

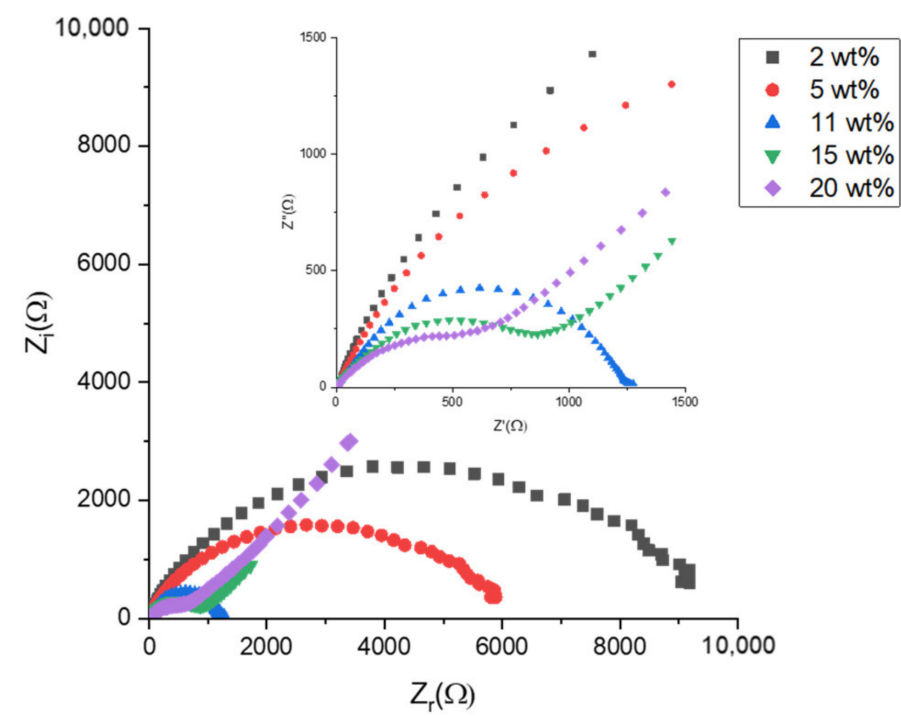

Figure 3. Impedance plot for $\mathrm{CH} / \mathrm{Na}$ polymer matrix with different weight percentages of CuSe filler measured at room temperature. 
The $R_{B}$ value obtained from the Nyquist plot was used to calculate the conductivity of the polymer matrix. Table 1 shows that the conductivity of the polymer matrix increases as the concentration of CuSe filler increases. The incorporation of CuSe filler in the $\mathrm{CH} / \mathrm{Na} / \mathrm{CuSe}$ polymer matrix showed an increment in conductivity from the pure chitosan polymer conductivity of $4.2 \times 10^{-9} \mathrm{~S} / \mathrm{cm}$ to $3.74 \times 10^{-7} \mathrm{~S} / \mathrm{cm}$, with a concentration of $2 \mathrm{wt} \%$ of CuSe filler. $\mathrm{Na}^{+}$and CuSe increased the number of charge carriers in the film and greatly improved conductivity. An increase in the weight percentage of CuSe filler further increased the conductivity value. The highest conductivity value was $4.377 \times 10^{-5} \mathrm{~S} / \mathrm{cm}$ for the sample with $20 \mathrm{wt} \%$ of CuSe filler. An increase in conductivity changed the chitosan polymer from an insulator to an electroactive polymeric composite.

Table 1. Electrical properties of $\mathrm{CH} / \mathrm{Na} / \mathrm{CuSe}$ polymer matrix with different $\mathrm{wt} \%$ of $\mathrm{CuSe}$ fillers.

\begin{tabular}{|c|c|c|c|}
\hline CuSe (wt\%) & $\begin{array}{c}\text { Film Thickness } \\
(\mathrm{mm})\end{array}$ & $\begin{array}{c}\text { Bulk Resistance, } R_{B} \\
(\Omega)\end{array}$ & $\begin{array}{c}\text { Conductivity, } \sigma \\
(\mathrm{S} / \mathrm{cm})\end{array}$ \\
\hline 2 & 0.119 & $10,123.0$ & $3.74 \times 10^{-7}$ \\
\hline 5 & 0.125 & 6575.1 & $6.05 \times 10^{-7}$ \\
\hline 11 & 0.132 & 1265.8 & $3.32 \times 10^{-6}$ \\
\hline 15 & 0.142 & 816.61 & $5.54 \times 10^{-6}$ \\
\hline 20 & 0.152 & 442.18 & $3.69 \times 10^{-5}$ \\
\hline
\end{tabular}

\subsection{Dielectric Properties}

Figure $4 \mathrm{a}$ shows the dielectric constant as a function of frequency for the $\mathrm{CH} / \mathrm{Na} / \mathrm{CuSe}$ polymer matrix with different weight percentages of CuSe filler. All measured samples showed dependency on frequency with a decreasing value as the frequency increased. This corresponded to the electrode polarisation effects, indicating space charge effects that occurred at low frequency [42]. At high frequency, the material experienced a higher reversal of electric field that caused no excess ions to diffuse in the electric field direction. This caused a decrease in polarisation and contributed to the decreased value for $\varepsilon_{\mathrm{r}}$ and $\varepsilon_{\mathrm{i}}$ as the frequency increased [43]. This phenomenon was confined to non-Derby behaviour in the polymer matrix film. The dielectric loss of the $\mathrm{CH} / \mathrm{Na} / \mathrm{CuSe}$ polymer matrix with a different weight percentage of CuSe filler is shown in Figure $4 \mathrm{~b}$. The dielectric loss in samples decreased as frequency increased. The dielectric loss was found to be higher in a polymer matrix with a higher weight percentage of $\mathrm{CuSe}$ filler. The higher dielectric loss was due to more free electrons in samples with higher CuSe filler concentrations, making the energy dissipation through the movement of charge easier in the alternating field. The $\varepsilon_{\mathrm{r}}$ and $\varepsilon_{\mathrm{i}}$ followed the same trend as conductivity, whereby the film with the highest conductivity had the highest $\varepsilon_{\mathrm{r}}$ and $\varepsilon_{\mathrm{i}}$. Other works also reported that a higher number of charge carriers would contribute to a higher conductivity and dielectric constant [44,45].

\subsection{EMI Shielding Property}

The EMI shielding efficiency (SE) values of the $\mathrm{CH} / \mathrm{Na} / \mathrm{CuSe}$ polymer matrix with different $\mathrm{wt} \%$ of $\mathrm{CuSe}$ filler were determined at a frequency range of $8 \mathrm{GHz}$ to $12 \mathrm{GHz}$. Figure 5 shows the $S E$ results due to reflection $\left(S_{R}\right)$ of samples. The measured $S E_{R}$ showed low dependency with frequency within the measurement region, with scattering observed in samples with $11 \mathrm{wt} \%$ and higher. For samples of $2 \mathrm{wt} \%, 5 \mathrm{wt} \%$, and $11 \mathrm{wt} \%$, an average of less than $1 \mathrm{~dB}$ was observed in all samples. The $\mathrm{CH} / \mathrm{Na} / \mathrm{CuSe}$ polymer matrix with $15 \mathrm{wt} \%$ produced higher $\mathrm{SE}_{\mathrm{R}}$, with an average of $1.5 \mathrm{~dB}$ measured. The highest $\mathrm{SE}_{\mathrm{R}}$ was measured for the $\mathrm{CH} / \mathrm{Na} / \mathrm{CuSe}$ polymer matrix with $20 \mathrm{wt} \% \mathrm{CuSe}$ filler with an average of $3.12 \mathrm{~dB}$, which was equivalent to $50 \%$ of the EM energy being shielded due to the reflection. 


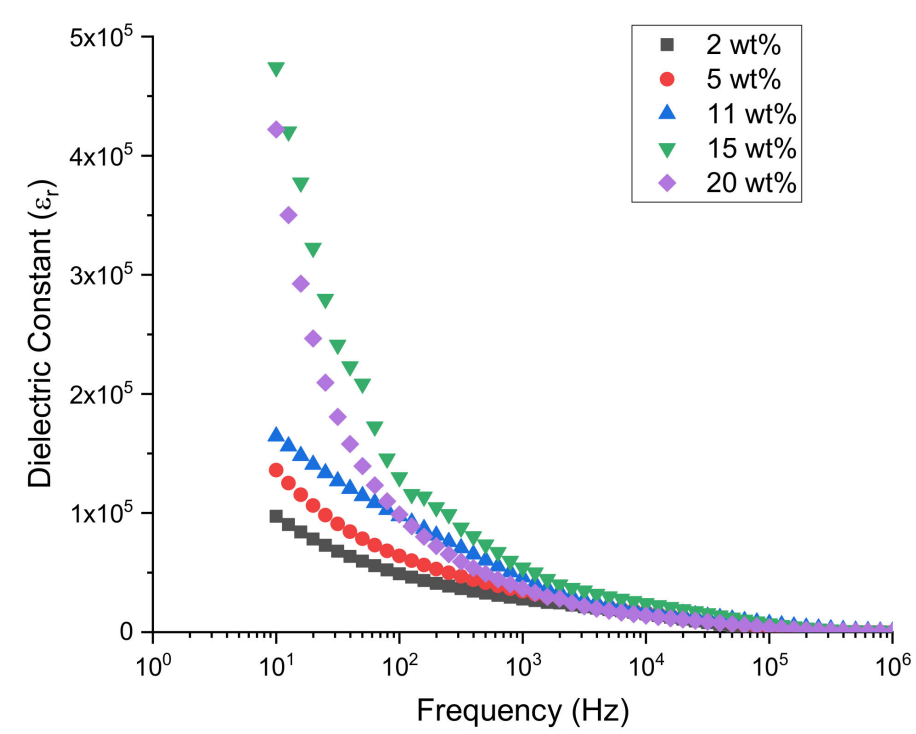

(a)

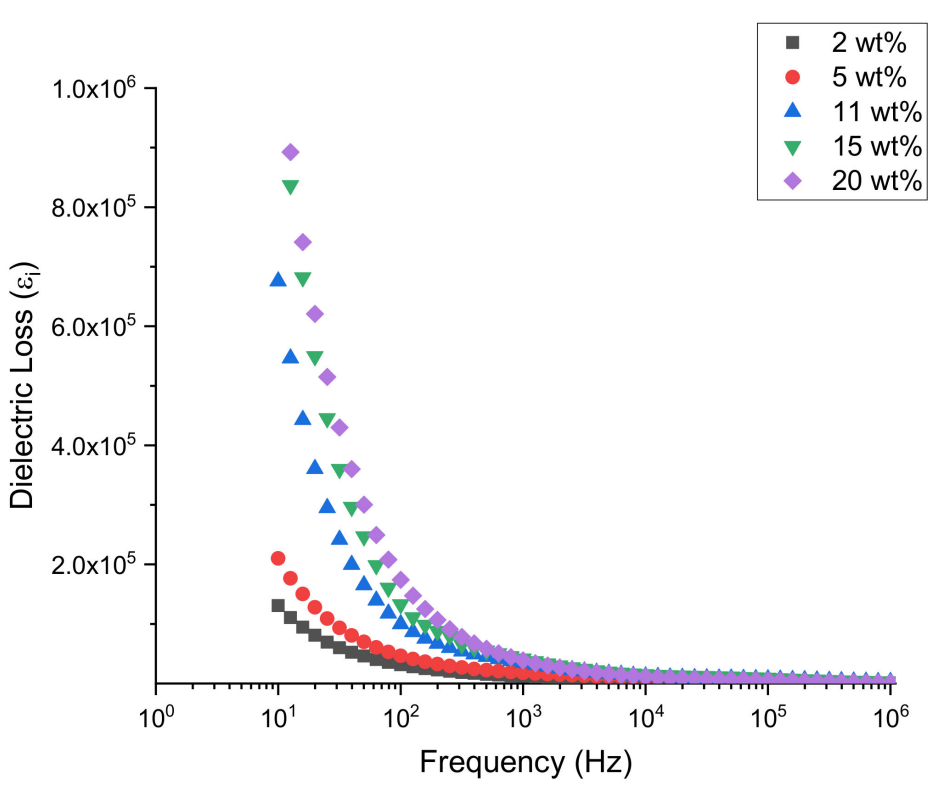

(b)

Figure 4. (a) Dielectric constant and (b) dielectric loss for $\mathrm{CH} / \mathrm{Na} / \mathrm{CuSe}$ polymer matrix with different $\mathrm{w} \mathrm{t} \%$ of CuSe filler measured at room temperature.

It was observed that the $\mathrm{CH} / \mathrm{Na} / \mathrm{CuSe}$ polymer matrix with a higher concentration of CuSe filler produced a higher $\mathrm{SE}_{\mathrm{R}}$. The $\mathrm{SE}_{\mathrm{R}}$ value can be associated with the mismatch between the shielding material surface impedance and electromagnetic wave. From Equation (7), it was noticed that the conductivity of the shielding material dominated the $\mathrm{SE}_{\mathrm{R}}$ value. A shielding material with higher conductivity produced a higher $\mathrm{SE}_{\mathrm{R}}$. Therefore, the $\mathrm{CH} / \mathrm{Na} / \mathrm{CuSe}$ polymer matrix with a higher concentration of CuSe filler produced a higher $\mathrm{SE}_{\mathrm{R}}$, as it had higher conductivity. 


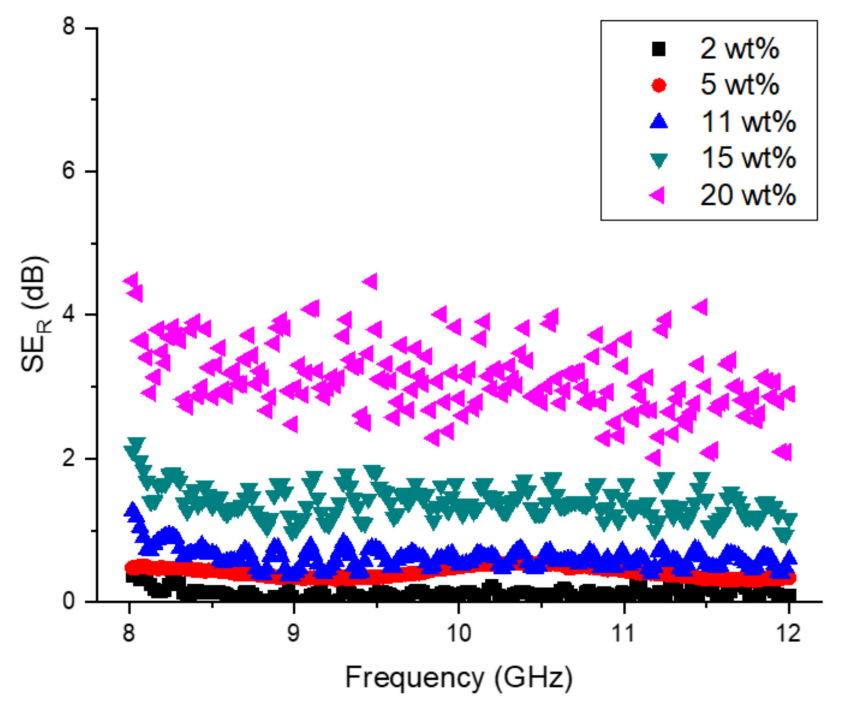

Figure 5. Shielding efficiency due to the reflection of $\mathrm{CH} / \mathrm{Na} / \mathrm{CuSe}$ polymer matrix with $2 \mathrm{wt} \%$ to $20 \mathrm{wt} \%$ of CuSe filler.

Figure 6 shows the $\mathrm{SE}$ results due to absorption $\left(\mathrm{SE}_{\mathrm{A}}\right)$ of the sample. For the $\mathrm{CH} / \mathrm{Na}$ / CuSe polymer matrix with $2 \mathrm{wt} \%$ of CuSe filler, nearly $0 \mathrm{~dB}$ of $\mathrm{SE}_{\mathrm{A}}$ was measured. This was equivalent to almost no EM energy being shielded from absorption. The $\mathrm{SE}_{\mathrm{A}}$ value was observed to increase as the concentration of CuSe was increased. At $5 \mathrm{wt} \%$ of CuSe filler, an average of $2 \mathrm{~dB}$ was measured, while at $11 \mathrm{wt} \%$, an average of $4.5 \mathrm{~dB}$ was measured. The highest $\mathrm{SE}_{\mathrm{A}}$ was measured for $20 \mathrm{wt} \%$ of CuSe filler, whereby an average of $16.4 \mathrm{~dB}$ was measured. It was also observed from Figures 5 and 6 that a higher $\mathrm{SE}_{\mathrm{A}}$ value was observed in all $\mathrm{CH} / \mathrm{Na} / \mathrm{CuSe}$ polymer matrices as compared to the $\mathrm{SE}_{\mathrm{R}}$ value.

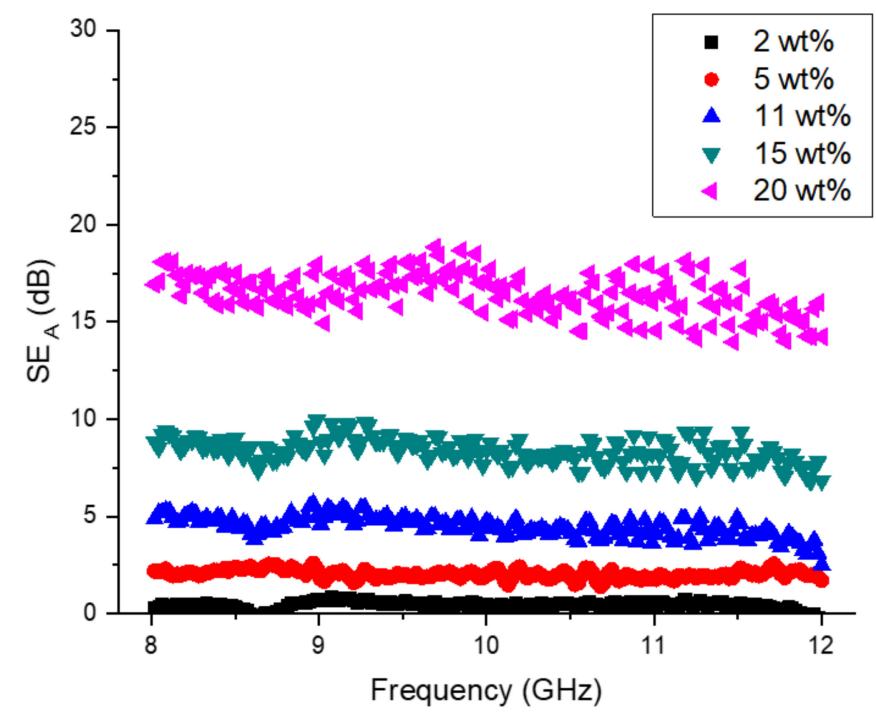

Figure 6. Shielding efficiency due to absorption for $\mathrm{CH} / \mathrm{Na} / \mathrm{CuSe}$ polymer matrix with $2 \mathrm{wt} \%$ to $20 \mathrm{wt} \%$ of CuSe filler.

The $\mathrm{SE}_{\mathrm{A}}$ value mainly contributed through the ohmic loss of shielding material. The increase in $\mathrm{SE}_{\mathrm{A}}$ as the concentration of CuSe filler increased can be related to the conductivity of the material. From Equation (10), it was noted that the $\mathrm{SE}_{\mathrm{A}}$ was also the function of material conductivity $(\sigma)$. Therefore, the material with the highest conductivity will produce a higher $\mathrm{SE}_{\mathrm{A}}$. This was in agreement with the results obtained. The $\mathrm{SE}_{\mathrm{A}}$ was also a function of material permeability $(\mu)$. For a nonmagnetic material, the $\mu$ is equal to 
$\mu_{\mathrm{o}} \mu_{\mathrm{r}}$. The $\mu_{\mathrm{r}}$ can be considered as equal to 1 in all samples because the CuSe filler was a nonmagnetic material; hence, the $\mu$ is equal to $\mu_{\mathrm{o}}\left(4 \pi \times 10^{-7} \mathrm{Hm}^{-1}\right)$.

Boundary conditions between two materials with different properties also govern the electromagnetic reaction. At the boundary between two different materials, some of the incident waves will be transmitted, and some will be reflected. The amplitudes and directions of the reflected waves will depend on the types of material at the boundary and the incidence angle. For a normal incident in the air to a perfect electrical conductor boundary, a high surface charge $\left(\rho_{\mathrm{s}}\right)$ in the perfect electrical conductor causes the tangential electric field to cancel $\left(E_{t}=0\right)$. The normal electric field $\left(E_{n}\right)$, however, still exists. The $E_{n}$ is related to surface charge and the permittivity of the perfect electrical conductor by

$$
\mathrm{E}_{\mathrm{n}}=\frac{\rho_{\mathrm{s}}}{\varepsilon}
$$

Equation (11) is also valid for other types of materials. In the case of semiconducting materials, a lower $\rho_{\mathrm{s}}$ will cause $\mathrm{E}_{\mathrm{t}}$ not to equal zero, and the $\mathrm{E}_{\mathrm{n}}$ value will be lower. This will contribute to higher transmitted and lower reflected waves at the boundary as compared to a perfect electrical conductor.

Higher scattering was observed in the $\mathrm{SE}_{\mathrm{A}}$ and $\mathrm{SE}_{\mathrm{R}}$ plots for the $\mathrm{CH} / \mathrm{Na} / \mathrm{CuSe}$ polymer matrix with a higher CuSe filler concentration. This can be contributed to the surface condition of the polymer sample that causes scattering of electromagnetic waves upon incident on to the surface [46]. From the AFM image in Figure 7, it is shown that the sample with $2 \mathrm{wt} \%$ of the CuSe filler had a smoother and uniform surface with a variation of roughness between $2 \mathrm{~nm}$ and $15 \mathrm{~nm}$ compared to the $20 \mathrm{wt} \%$ CuSe filler with a higher surface roughness of up to $200 \mathrm{~nm}$ due to the agglomeration of $\mathrm{CuSe}$ filler in the sample. This contributes to the irregular reflection of the EM waves and higher scattering in the sample with $20 \mathrm{wt} \%$ of CuSe. The scattering, however, did not affect the polymer overall shielding performance.

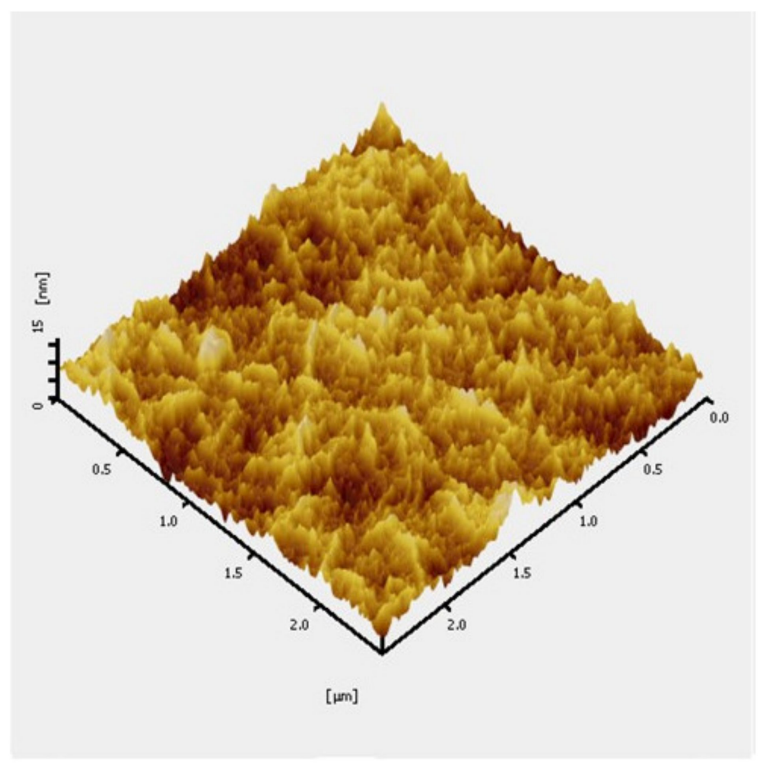

(a)

Figure 7. Cont. 


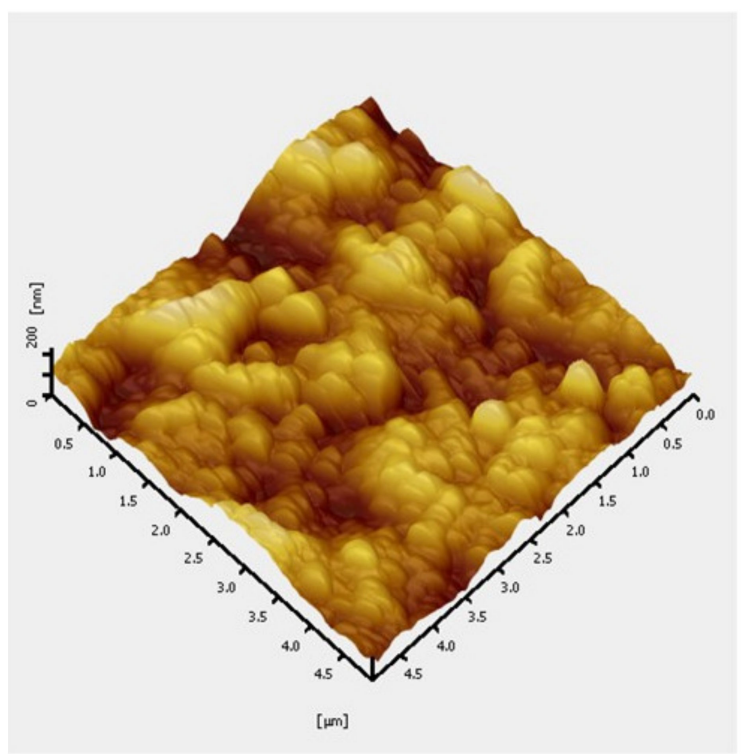

(b)

Figure 7. The 3-dimensional AFM image for (a) $2 \mathrm{wt} \%$ and (b) $20 \mathrm{wt} \%$ of CuSe filler in $\mathrm{CH} / \mathrm{Na} / \mathrm{CuSe}$ polymer matrix.

The total shielding effectiveness for the $\mathrm{CH} / \mathrm{Na} / \mathrm{CuSe}$ polymer matrix with $\mathrm{CuSe}$ filler is shown in Figure 8. The $\mathrm{CH} / \mathrm{Na} / \mathrm{CuSe}$ polymer matrix with $2 \mathrm{wt} \% \mathrm{CuSe}$ filler was almost transparent to the electromagnetic wave, with an average total shielding of $0.54 \mathrm{~dB}$, or only $11.7 \%$ of the EM power being shielded. The $\mathrm{CH} / \mathrm{Na} / \mathrm{CuSe}$ polymer matrix with $5 \mathrm{wt} \% \mathrm{CuSe}$ filler produced a slightly better total shielding with an average value of $2.44 \mathrm{~dB}$, which corresponded to $42.9 \%$ shielded EM energy. A good total shielding efficiency was observed in the $\mathrm{CH} / \mathrm{Na} / \mathrm{CuSe}$ polymer matrix with $11 \mathrm{wt} \%$ and $15 \mathrm{wt} \%$ of CuSe filler, whereby these samples shielded more than half of the EM energy. The $\mathrm{CH} / \mathrm{Na} / \mathrm{CuSe}$ polymer matrix with $11 \mathrm{wt} \%$ of CuSe filler showed an average of $5.08 \mathrm{~dB}$ total shielding, corresponding to $70 \%$ EM energy reduction. Meanwhile, the polymer matrix with $15 \mathrm{wt} \%$ CuSe filler produced $9.75 \mathrm{~dB}$ of average efficiency, consistent with $89.4 \% \mathrm{EM}$ of energy shielded. An average of $19.55 \mathrm{~dB}$ total shielding was measured for the $\mathrm{CH} / \mathrm{Na} / \mathrm{CuSe}$ polymer matrix with $20 \mathrm{wt} \% \mathrm{CuSe}$ filler, which produced $98.88 \%$ EM energy shielding.

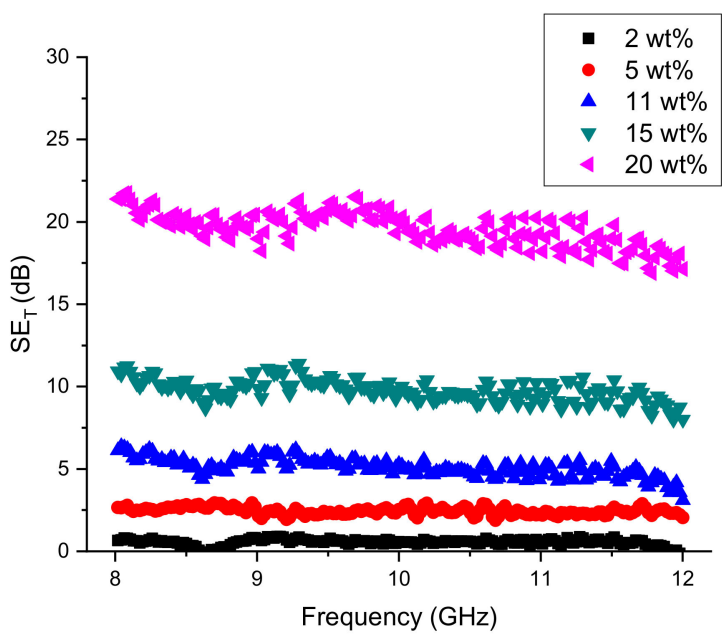

Figure 8. Total shielding efficiency of $\mathrm{CH} / \mathrm{Na} / \mathrm{CuSe}$ polymer matrix with $2 \mathrm{wt} \%$ to $20 \mathrm{wt} \%$ of CuSe filler. 
An improvement in the total EMI SE of the $\mathrm{CH} / \mathrm{Na}$ /CuSe polymer matrix with CuSe filler for shielding purposes can be made by increasing the sample thickness. Figure 9 shows the measured total shielding efficiency for the $\mathrm{CH} / \mathrm{Na} / \mathrm{CuSe}$ polymer matrix with $20 \mathrm{wt} \% \mathrm{CuSe}$ filler as the thickness was increased. When the thickness was doubled from initial thickness, the average total shielding increased from $19.52 \mathrm{~dB}$ to $24.93 \mathrm{~dB}$, this corresponding to an increase from $98.88 \%$ to $99.67 \%$ of EM energy shielded. At a thickness of $0.513 \mathrm{~mm}$, the average recorded $\mathrm{SE}_{\mathrm{T}}$ was $28.15 \mathrm{~dB}$, with total shielding of $99.84 \%$ of EM energy. The highest total shielding of above $34.44 \mathrm{~dB}$ was measured at a thickness of $0.608 \mathrm{~mm}$. The $34.44 \mathrm{~dB}$ shielding was equivalent to $99.96 \%$ of EM power and was shielded by the $\mathrm{CH} / \mathrm{Na} / \mathrm{CuSe}$ polymer matrix. No resonance was observed as the thickness of $\mathrm{CH} / \mathrm{Na} / \mathrm{CuSe}$ polymer matrix was increased.

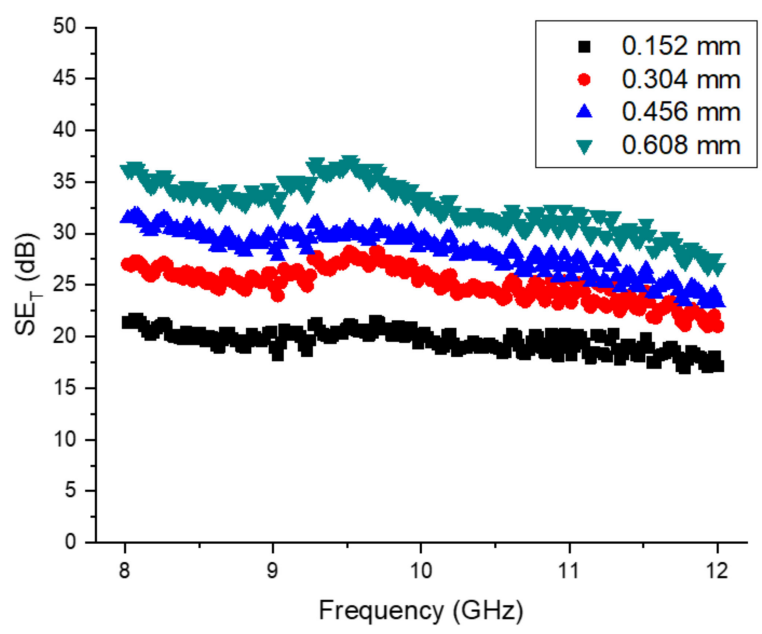

Figure 9. Effect of thickness on total shielding efficiency of $\mathrm{CH} / \mathrm{Na} / \mathrm{CuSe}$ polymer matrix with $20 \mathrm{wt} \%$ of CuSe filler.

The EMI shielding performance of the $\mathrm{CH} / \mathrm{Na} / \mathrm{CuSe}$ presented in this work was compared with other similar works reported in the literature, focusing on works having polymer matrix thicknesses less than $1 \mathrm{~mm}$ [47-60]. From Figure 10, it can be seen that the SE value obtained from this work is comparable and within the range of SE reported in other works. The SE obtained for the $\mathrm{CH} / \mathrm{Na} / \mathrm{CuSe}$ can also be further increased by increasing the $w \mathrm{t} \%$ of CuSe.

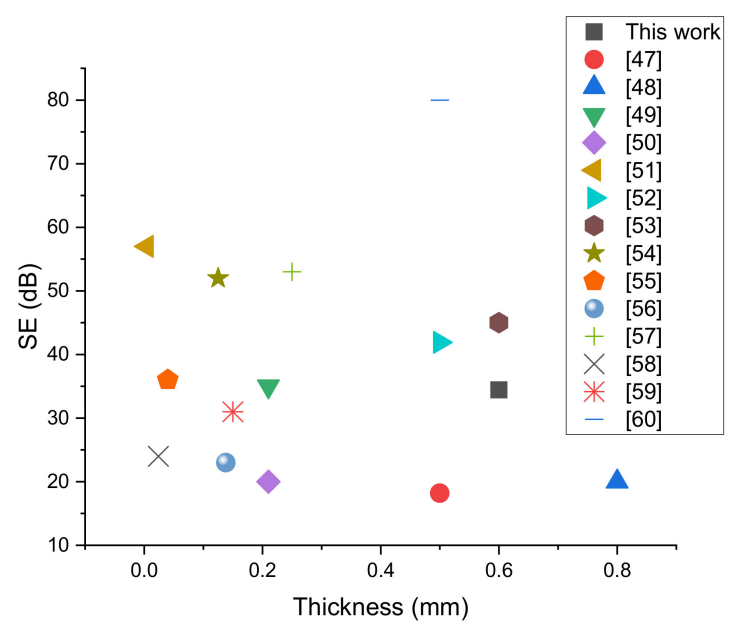

Figure 10. Comparison with reported SE in the literature for polymer composites with thickness less than $1 \mathrm{~mm}$ at frequency between 8 to $12 \mathrm{GHz}$. 


\section{Conclusions}

The $\mathrm{CH} / \mathrm{Na} / \mathrm{CuSe}$ polymer matrix with different $\mathrm{w} t \% \mathrm{CuSe}$ fillers was successfully prepared and showed good conductivity and total shielding efficiency. Improvement in electrical conductivity was from $3.74 \times 10^{-7}$ to $3.69 \times 10^{-5} \mathrm{~S} / \mathrm{cm}$ as CuSe concentration increased from $2 \mathrm{wt} \%$ to $20 \mathrm{wt} \%$. The conductivity that was increased by adding the $\mathrm{Na}$ and CuSe changed the $\mathrm{CH}$ polymer from a pure dielectric to a conducting polymer. The polymer exhibited a non-Derby behaviour, with higher $\varepsilon_{\mathrm{r}}$ and $\varepsilon_{\mathrm{i}}$ observed in samples with higher CuSe concentrations. The $\varepsilon_{\mathrm{r}}$ and $\varepsilon_{\mathrm{i}}$ also showed dependency on frequency with a decreasing value as frequency was increased. The total electromagnetic interference (EMI) shielding efficiency $\left(\mathrm{SE}_{\mathrm{T}}\right)$ showed an increment with the increment of CuSe in the polymer matrix. The $\mathrm{SE}_{\mathrm{T}}$ increased from $0.54 \mathrm{~dB}$ to $19.55 \mathrm{~dB}$ for the sample between $2 \mathrm{wt} \%$ and $20 \mathrm{wt} \%$. This corresponded to an $87.1 \%$ increment in the EM power shield. It was observed that absorption $\left(\mathrm{SE}_{\mathrm{A}}\right)$ was the primary mechanism as compared to reflection $\left(\mathrm{SE}_{\mathrm{R}}\right) . \mathrm{SE}_{\mathrm{T}}$ can be further increased up to $34 \mathrm{~dB}(99.9 \%$ power shield) when the thickness of the $20 \mathrm{wt} \%$ polymers is increased to $0.608 \mathrm{~mm}$. The results showed that the $\mathrm{CH} / \mathrm{Na} / \mathrm{CuSe}$ polymer was suitable for EMI shielding applications.

Author Contributions: Conceptualization, N.H.O.; methodology, N.H.O., N.N.M., M.A.H.M.A.M., J.Y.C.L. and H.I.M.; validation, N.H.O., J.Y.C.L. and M.M.R.; formal analysis, N.H.O., N.N.M., J.Y.C.L. and M.M.R.; writing—original draft preparation, N.H.O. and N.N.M.; writing—review and editing, N.H.O., M.N., A.V.S. and N.N.M. All authors have read and agreed to the published version of the manuscript.

Funding: This research was funded by Ministry of Education under Fundamental Research Grant Scheme (FRGS/1/2018/STG07/UPM/02/6).

Institutional Review Board Statement: Not applicable.

Informed Consent Statement: Not applicable.

Acknowledgments: This work was supported by the Ministry of Education and Department of Physics, Faculty of Science, Universiti Putra Malaysia, under the Fundamental Research Grant Scheme (FRGS/1/2018/STG07/UPM/02/6). The authors would like to extend their gratitude to the Department of Physics, Częstochowa University of Technology, Częstochowa, Poland.

Conflicts of Interest: The authors declare that they have no conflict of interest.

\section{References}

1. Sicard, E.; Dienot, J.M. Issues in electromagnetic compatibility of integrated circuits: Emission and susceptibility. Microelectron. Reliab. 2005, 45, 1277-1284. [CrossRef]

2. Geetha, S.; Kumar, K.K.S.; Rao, C.R.K.; Vijayan, M.; Trivedi, D.C. EMI shielding: Methods and materials-A review. J. Appl. Polym. Sci. 2009, 112, 2073-2086. [CrossRef]

3. Wang, K.; Ma, Q.; Zhang, Y.; Wang, S.; Han, G. Ag NPs-Assisted Synthesis of Stable Cu NPs on PET Fabrics for Antibacterial and Electromagnetic Shielding Performance. Polymers 2020, 12, 783. [CrossRef] [PubMed]

4. Yang, K.; Periyasamy, A.P.; Venkataraman, M.; Militky, J.; Kremenakova, D.; Vecernik, J.; Pulíček, R. Resistance against Penetration of Electromagnetic Radiation for Ultra-light Cu/Ni-Coated Polyester Fibrous Materials. Polymers 2020, 12, 2029. [CrossRef] [PubMed]

5. Kim, J.; Lee, S.; Kim, C.; Park, Y.; Kim, M.-H.; Seol, J.H. Electromagnetic Interference Shield of Highly Thermal-Conducting, Light-Weight, and Flexible Electrospun Nylon 66 Nanofiber-Silver Multi-Layer Film. Polymers 2020, 12, 1805. [CrossRef]

6. Vyas, M.K.; Chandra, A. Ion-Electron-Conducting Polymer Composites: Promising Electromagnetic Interference Shielding Material. ACS Appl. Mater. Interfaces 2016, 8, 18450-18461. [CrossRef] [PubMed]

7. Jiang, D.; Murugadoss, V.; Wang, Y.; Lin, J.; Ding, T.; Wang, Z.; Shao, Q.; Wang, C.; Liu, H.; Lu, N.; et al. Electromagnetic Interference Shielding Polymers and Nanocomposites-A Review. Polym. Rev. 2019, 59, 280-337. [CrossRef]

8. Thirumavalavan, S.; Mani, K.; Sagadevan, S. A study of structural, morphological, optical and electrical properties of Zinc Selenide (ZnSe) thin film. Mater. Today Proc. 2016, 3, 2305-2314. [CrossRef]

9. Bari, R.H.; Ganesan, V.; Potadar, S.; Patil, L.A. Structural, Optical and Electrical Properties of Chemically Deposited Copper Selenide Films. Bull. Mater. Sci. 2009, 32, 37. [CrossRef]

10. Xiao, G.; Ning, J.; Liu, Z.; Sui, Y.; Wang, Y.; Dong, Q.; Tian, W.; Liu, B.; Zou, G.; Zou, B. Solution synthesis of copper selenide nanocrystals and their electrical transport properties. CrystEngComm 2012, 14, 2139-2144. [CrossRef]

11. Heyding, R.D. The Copper/Selenium System. Can. J. Chem. 1966, 44, 1233-1236. [CrossRef] 
12. Al-Mamun; Islam, A.B.M.O; Bhuiyan, A.H. Structural, electrical and optical properties of copper selenide thin films deposited by chemical bath deposition technique. J. Mater. Sci. Mater. Electron. 2005, 16, 263-268. [CrossRef]

13. Pejova, B.; Grozdanov, I. Chemical Deposition and Characterization of $\mathrm{Cu}_{3} \mathrm{Se}_{2}$ and CuSe Thin Films. J. Solid State Chem. 2001, 158, 49-54. [CrossRef]

14. Nelson, P.I.; Arthi, R.; Kannan, R.R.; Selvan, T.P.; Ajitha, E.; Ashina, A.; Vidhya, B. Influence of heat treatment on the properties of thermally evaporated copper selenide thin films. Mater. Lett. 2018, 223, 14-16. [CrossRef]

15. Zhang, A.Y.; Ma, Q.A.; Wang, Z.G.; Luü, M.K.; Yang, P.; Zhou, G.J. Controllable synthesis of copper selenide nanocrystals through a green paraffin-acetate method. Mater. Chem. Phys. 2010, 124, 916-921. [CrossRef]

16. Wu, Y.; Korolkov, I.; Qiao, X.; Zhang, X.; Wan, J.; Fan, X. Facile synthesis of CuSe nanoparticles and high-quality single-crystal two-dimensional hexagonal nanoplatelets with tunable near-infrared optical absorption. J. Solid State Chem. 2016, 238, 279-283. [CrossRef]

17. Kaur, H.; Kaur, J.; Singh, L. Influence of different deposition potential on the structural and optical properties of copper selenide nanowires. Superlattices Microstruct. 2016, 97, 85-93. [CrossRef]

18. Mansour, B.; Zawawi, I.; Elsayed-Ali, H.E.; Hameed, T.A. Preparation and characterization of optical and electrical properties of copper selenide sulfide polycrystalline thin films. J. Alloy. Compd. 2017, 740, 1125-1132. [CrossRef]

19. Wang, W.; Geng, Y.; Qian, Y.; Wang, C.; Liu, X. A convenient, low temperature route to nanocrystalline SnSe. Mater. Res. Bull. 1999, 34, 403-406. [CrossRef]

20. Liew, J.Y.; Talib, Z.A.; Zainal, Z.; Kamarudin, M.A.; Osman, N.H.; Lee, H.K. Structural and transport mechanism studies of copper selenide nanoparticles. Semicond. Sci. Technol. 2019, 34, 125017. [CrossRef]

21. Wang, C.-Y.; He, H.-X. Tunable optical and magnetic properties of Ni-doped CuSe nanowires using an anodic aluminum oxide template assisted hydraulic method. Nanotechnology 2019, 30, 315704. [CrossRef]

22. Shukla, S.K.; Mishra, A.K.; Arotiba, O.A.; Mamba, B.B. Chitosan-based nanomaterials: A state-of-the-art review. Int. J. Biol. Macromol. 2013, 59, 46-58. [CrossRef]

23. Osman, N.H.; Mazu, N.N.; Chyi, J.L.Y.; Ramli, M.M.; Majid, M.A.H.M.A.; Mazlan, H.I. Chitosan-Bentonite Crosslinked Film As Indicator for Copper (II) Ions Adsorption. Eur. Phys. J. Appl. Phys. 2021. [CrossRef]

24. Aziz, S.B.; Abdullah, O.G.; Rasheed, M.A.; Ahmed, H.M. Effect of High Salt Concentration (HSC) on Structural, Morphological, and Electrical Characteristics of Chitosan Based Solid Polymer Electrolytes. Polymers 2017, 9, 187. [CrossRef]

25. Aziz, S.B.; Brza, M.; Mohamed, P.A.; Kadir, M.; Hamsan, M.H.; Abdulwahid, R.; Woo, H. Increase of metallic silver nanoparticles in Chitosan: AgNt based polymer electrolytes incorporated with alumina filler. Results Phys. 2019, 13, 102326. [CrossRef]

26. Asnawi, A.S.F.M.; Aziz, S.B.; Nofal, M.M.; Hamsan, M.H.; Brza, M.A.; Yusof, Y.M.; Abdilwahid, R.T.; Muzakir, S.K.; Kadir, M.F.Z. Glycerolized $\mathrm{Li}^{+}$Ion Conducting Chitosan-Based Polymer Electrolyte for Energy Storage EDLC Device Applications with Relatively High Energy Density. Polymers 2020, 12, 1433. [CrossRef]

27. Bandara, T.M.W.J.; Mellander, B.E. Evaluation of Mobility, Diffusion Coefficient and Density of Charge Carriers in Ionic Liquids and Novel Electrolytes Based on a New Model for Dielectric Response. In Ionic Liquids: Theory, Properties, New Approaches; IntechOpen: London, UK, 2011; pp. 383-406.

28. Sebastian, M.T.; Ubic, R.; Jantunen, H. Microwave Materials and Applications, 1st ed.; John Wiley \& Sons: New York, NY, USA, 2017; pp. 575-672.

29. Yahya, M.Z.A.; Arof, A.K. Studies on lithium acetate doped chitosan conducting polymer system. Eur. Polym. J. 2002, 38, 1191-1197. [CrossRef]

30. Raagulan, K.; Braveenth, R.; Kim, B.M.; Lim, K.J.; Lee, S.B.; Kim, M.; Chai, K.Y. An effective utilization of MXene and its effect on electromagnetic interference shielding: Flexible, free-standing and thermally conductive composite from MXene-PAT-poly(paminophenol)-polyaniline co-polymer. RSC Adv. 2020, 10, 1613-1633. [CrossRef]

31. Sankaran, S.; Deshmukh, K.; Ahamed, M.B.; Pasha, S.K. Recent advances in electromagnetic interference shielding properties of metal and carbon filler reinforced flexible polymer composites: A review. Compos. Part A Appl. Sci. Manuf. 2018, $114,49-71$. [CrossRef]

32. Yamaguchi, I.; Tokuchi, K.; Fukuzaki, H.; Koyama, Y.; Takakuda, K.; Monma, H. Preparation and Microstructure Analysis of Chitosan/Hydroxyapatite Nanocomposites. J. Biomed. Mater. Res. 2001, 55, 20-27. [CrossRef]

33. Nugraheni, P.S.; Soeriyadi, A.H.; Sediawan, W.B.; Budhijanto, W. Influence of Salt Addition and Freezing-Thawing on Particle Size and Zeta Potential of Nano-Chitosan. In Proceedings of the IOP Conference Series: Earth and Environmental Science, Bogor, Indonesia, 9-10 October 2018; Volume 278.

34. Bhargav, P.B.; Mohan, V.M.; Sharma, A.K.; Rao, V.V.R.N. Structural and electrical studies of sodium iodide doped poly(vinyl alcohol) polymer electrolyte films for their application in electrochemical cells. Ionics 2007, 13, 173-178. [CrossRef]

35. Martinez-Cisneros, C.; Levenfeld, B.; Varez, A.; Sanchez, J. Development of sodium-conducting polymer electrolytes: Comparison between film-casting and films obtained via green processes. Electrochim. Acta 2016, 192, 456-466. [CrossRef]

36. Chandrasakaran, D.S.; Nainggolan, I.; Ikhsan, T.; Derman, N. Ammonia Gas Sensor Based on Chitosan Biopolymer. Mater. Sci. Forum 2015, 819, 429-434. [CrossRef]

37. Yadi, M.G.; Benguella, B.; Gaouar-Benyelles, N.; Tizaoui, K. Adsorption of ammonia from wastewater using low-cost bentonite/chitosan beads. Desalination Water Treat. 2016, 57, 21444-21454. [CrossRef] 
38. Haseena, P.; Padmavathy, K.; Krishnan, P.R.; Madhu, G. Adsorption of Ammonium Nitrogen from Aqueous Systems Using Chitosan-Bentonite Film Composite. Procedia Technol. 2016, 24, 733-740. [CrossRef]

39. Muthukannan, A.; Sivakumar, G.; Mohanraj, K. Influence of Equimolar Concentration on Structural and Optical Properties of Binary Selenides Nanoparticles. Part. Sci. Technol. 2014, 32, 392-398. [CrossRef]

40. Aziz, S.B.; Woo, T.J.; Kadir, M.F.Z.; Ahmed, H.M. A conceptual review on polymer electrolytes and ion transport models. J. Sci. Adv. Mater. Devices 2018, 3, 1-17. [CrossRef]

41. Mamunya, Y.; Davidenko, V.V.; Lebedev, É.V. Percolation conductivity of polymer composites filled with dispersed conductive filler. Polym. Compos. 1995, 16, 319-324. [CrossRef]

42. Elmezayyen, A.S.; Reicha, F.M. Preparation of Chitosan Copper Complexes: Molecular Dynamic Studies of Chitosan and Chitosan Copper Complexes. Open J. Appl. Sci. 2015, 5, 415-427. [CrossRef]

43. Rayssi, C.; El.Kossi, S.; Dhahri, J.; Khirouni, K. Frequency and temperature-dependence of dielectric permittivity and electric modulus studies of the solid solution Ca0.85Er0.1Ti1-xCo4x/3O3 $(0 \leq \mathrm{x} \leq 0.1)$. RSC Adv. 2018, 8, 17139-17150. [CrossRef]

44. Yusof, Y.M.; Illias, H.A.; Kadir, M.F.Z. Incorporation of NH4Br in PVA-chitosan blend-based polymer electrolyte and its effect on the conductivity and other electrical properties. Ionics 2014, 20, 1235-1245. [CrossRef]

45. Khiar, A.S.A.; Puteh, R.; Arof, A. Conductivity studies of a chitosan-based polymer electrolyte. Phys. B Condens. Matter 2006, 373, 23-27. [CrossRef]

46. Cao, L.; Sendur, K. Surface Roughness Effects on the Broadband Reflection for Refractory Metals and Polar Dielectrics. Materials 2019, 12, 3090. [CrossRef]

47. Yang, H.; Yu, Z.; Wu, P.; Zou, H.; Liu, P. Electromagnetic interference shielding effectiveness of microcellular polyimide/In Situ thermally reduced graphene oxide/carbon nanotubes nanocomposites. Appl. Surf. Sci. 2018, 434, 318-325. [CrossRef]

48. Li, Y.; Pei, X.; Shen, B.; Zhai, W.; Zhang, L.; Zheng, W. Polyimide/graphene composite foam sheets with ultrahigh thermostability for electromagnetic interference shielding. RSC Adv. 2015, 5, 24342-24351. [CrossRef]

49. Al-Saleh, M.; Gelves, G.A.; Sundararaj, U. Copper nanowire/polystyrene nanocomposites: Lower percolation threshold and higher EMI shielding. Compos. Part A Appl. Sci. Manuf. 2011, 42, 92-97. [CrossRef]

50. Gelves, G.A.; Al-Saleh, M.; Sundararaj, U. Highly electrically conductive and high performance EMI shielding nanowire/polymer nanocomposites by miscible mixing and precipitation. J. Mater. Chem. 2011, 21, 829-836. [CrossRef]

51. Shahzad, F.; Alhabeb, M.; Hatter, C.B.; Anasori, B.; Hong, S.M.; Koo, C.M.; Gogotsi, Y. Electromagnetic interference shielding with 2D transition metal carbides (MXenes). Science 2016, 353, 1137-1140. [CrossRef]

52. Singh, R.; Kulkarni, S.G. Nanocomposites based on transition metal oxides in polyvinyl alcohol for EMI shielding application. Polym. Bull. 2013, 71, 497-513. [CrossRef]

53. Anupama, J.; Anil, B.; Rajvinder, S.; Alegaonkar, P.S.; Balasubramanian, K.; Suwarna, D. Graphene Nanoribbon-PVA Composite as EMI Shielding Material in the X band. Nanotechnology 2013, 24, 455705.

54. Wan, Y.-J.; Zhu, P.-L.; Yu, S.-H.; Sun, R.; Wong, C.-P.; Liao, W.-H. Graphene paper for exceptional EMI shielding performance using large-sized graphene oxide sheets and doping strategy. Carbon 2017, 122, 74-81. [CrossRef]

55. Zhang, Y.; Wang, L.; Zhang, J.; Song, P.; Xiao, Z.; Liang, C.; Qiu, H.; Kong, J.; Gu, J. Fabrication and investigation on the ultra-thin and flexible Ti3C2Tx/co-doped polyaniline electromagnetic interference shielding composite films. Compos. Sci. Technol. 2019, 183, 107833. [CrossRef]

56. Parit, M.; Du, H.; Zhang, X.; Prather, C.; Adams, M.; Jiang, Z. Polypyrrole and cellulose nanofiber based composite films with improved physical and electrical properties for electromagnetic shielding applications. Carbohydr. Polym. 2020, $240,116304$. [CrossRef] [PubMed]

57. Zahid, M.; Nawab, Y.; Gulzar, N.; Rehan, Z.A.; Shakir, M.F.; Afzal, A.; Rashid, I.A.; Tariq, A. Fabrication of reduced graphene oxide (RGO) and nanocomposite with thermoplastic polyurethane (TPU) for EMI shielding application. J. Mater. Sci. Mater. Electron. 2010, 31, 967-974. [CrossRef]

58. Li, Y.; Shen, B.; Pei, X.; Zhang, Y.; Yi, D.; Zhai, W.; Zhang, L.; Wei, X.; Zheng, W. Ultrathin carbon foams for effective electromagnetic interference shielding. Carbon 2016, 100, 375-385. [CrossRef]

59. Chaudhary, A.; Kumari, S.; Kumar, R.; Teotia, S.; Singh, B.P.; Singh, A.P.; Dhawan, S.K.; Dhakate, S.R. Lightweight and Easily Foldable MCMB-MWCNTs Composite Paper with Exceptional Electromagnetic Interference Shielding. ACS Appl. Mater. Interfaces 2016, 8, 10600-10608. [CrossRef]

60. Chaudhary, A.; Kumar, R.; Teotia, S.; Dhawan, S.K.; Dhakate, S.R.; Kumari, S. Integration of $\mathrm{MCMBs} / \mathrm{MWCNTs}$ with Fe $\mathrm{O}_{4}$ in a flexible and light weight composite paper for promising EMI shielding applications. J. Mater. Chem. C 2016, 5, 322-332. [CrossRef] 